УДК 633.522:631.52

(C) 2013

Міщенко С. В., кандидат сільськогосподарських наук

Дослідна станція луб'яних культур Інституту сільського господарства Північного Сходу НААН України

\title{
ЗАЛЕЖНІСТЬ СХОЖОСТІ НАСІННЯ САМОЗАПИЛЕНИХ ЛІНІЙ КОНОПЕЛЬ ВІД ПОКОЛІННЯ Й ТРИВАЛОСТІ ЗБЕРІГАННЯ
}

\section{Рецензент - кандидат сільськогосподарських наук К. В. Конопля}

У статті розглянуто один із аспектів впливу інбридингу (самозапилення) на прояв депресії ознак енертї проростання й схожості насіння сучасних сортів конопель (Cannabis sativa L.). Встановлено, щзо зі збільшенням тривалості зберігання насіння енертія його проростання і схожість знижується. В разі самозапилення спостерігається чітке зниження показників енертї̈ проростання від популяції сорту до $I_{5}$, щзо характерно для всіх досліджуваних ліній (зразків). Значні межі варіювання ознак енертї проростання й схожості $(h-$ від 1 до 68) дають підстави стверджувати про генотипову залежність даної ознаки.

Ключові слова: коноплі, самозапилені лінї, енергія проростання насіння, схожість насіння, депресія.

Постановка проблеми. 3-поміж великого видового різноманіття рослин спостерігаються різні ступені вираження аутбридингу й інбридингу. Крайній ступінь вираження інбридингу - самозапилення - властивий значній кількості рослин. У багатьох же видів існують біологічні й генетичні бар'єри, які перешкоджають схрещуванню між близькоспорідненими особинами, навіть, існують алелі несумісності [2]. На сучасному етапі розвитку селекції й сільськогосподарського виробництва інбридинг знайшов широке застосування у більшості перехреснозапильних культур.

Інбридинг дає можливість не тільки посилити домінантні ознаки, очистити особини від шкідливих рецесивних генів, але й виокремити із популяції перехресників нові форми 3 корисними для людини рецесивними ознаками, прихованими у вільно схрещуваних популяціях. Основне значення інбридингу полягає у створенні за короткий проміжок часу гомозиготного потомства. Підвищення ж продуктивності рослин досягається в процесі гібридизації ліній на основі використання ефекту гетерозису [7].

Інбридинг у конопель (Cannabis sativa L.) досліджували Сизов И. А., Степанов Г. С., Мигаль Н. Д., Лайко И. М., Ситник В. П., В Вировец В. Г., Fruwirth C., Hirata K., Hoffmann W., Fleischmann R., Bócsa I., Crescini F., Wichert-
Kobus J., Tran Van Lai та ін. (іхній внесок описано в оглядовій праці [5]), однак недостатньо, поскільки цитоплазматична чоловіча стерильність не виявлена, і самозапилені лінії для створення гетерозисних гібридів не використовувалися. Постає проблема комплексного та всебічного вивчення біологічних і селекційних ознак самозапилених ліній, у т. ч. й залежності схожості насіння від покоління та тривалості зберігання.

Аналіз останніх досліджень і публікацій, у яких започатковано розв'язання проблеми. Про різке зменшення насіннєвої продуктивності в процесі близькоспорідненого розмноження повідомляє Г. С. Степанов, наводячи наступні дані: якщо вихідна форма мала 360-380 насінин на одному суцвітті, то рослини $\mathrm{I}_{1}-10-16(2,7-4,1 \%)$, $\mathrm{I}_{2}-3-6(2,2-3,1 \%), \mathrm{I}_{3}-5-6(1,3-1,5 \%), \mathrm{I}_{4}-3-6$ $(0,8-1,5 \%), \mathrm{I}_{5}-2-5$ штук $(0,5-1,2 \%)$ [6]. На основі досліджень автор констатує, що результатом депресії при інбридингу є явище зниження схожості насіння. Уже в першому поколінні вона становила 5,5-10,0 \% і в подальшому від покоління до покоління знижувалася до 3,3-5,5 \% ( $\left.\mathrm{I}_{5}\right)$. У багатьох випадках втрата фертильності внаслідок самозапилення була настільки значною, що не було можливості отримати потомство у четвертій і п'ятій генераціях [6]. Незважаючи на це, питання дослідження якості насіння, зокрема енергіï проростання і схожості, у самозапилених ліній сучасних сортів різного походження і груп стиглості залишається актуальним.

Неабияке значення в біологічному рослинництві має якісний насінний матеріал. Він дає можливість без додаткових затрат на добрива, пестициди, ретарданти i дефоліанти забезпечити ріст рослин, знизити (а то й звести до мінімуму) негативний вплив бур'янів, хвороб, шкідників i на цій основі підвищити врожайність культури та іiі якість, поліпшити екологічні умови поля, сівозміни й агроландшафту в цілому [1]. Основними показниками якості насіння є чистота, маса 1000 насінин, вологість, енергія проростання, лабораторна схожість [1]. 
Схожість - це кількість нормально пророслого насіння за певний час, виражена у відсотках до загальної його кількості, взятої для пророщування. Лабораторну схожість визначають шляхом пророщування в оптимальних умовах упродовж встановленого для кожної культури терміну. Польова схожість нижча за лабораторну, бо в полі гірші умови проростання насіння [4]. Одночасно зі схожістю встановлюють і енергію проростання, тобто кількість нормально пророслих насінин за перші 3-4 доби пророщування. Даний показник характеризує здатність насіння давати в польових умовах дружні, вирівняні сходи, що гарантує високе виживання рослин за вегетаційний період [4].

Мета досліджень - встановити вплив крайньої форми інбридингу самозапилення на репродукційні можливості конопель, зокрема на схожість насіння та енергію проростання.

Завдання досліджень:

1. Виявити залежність енергіï проростання та схожості насіння самозапилених ліній сучасних сортів конопель різного еколого-географічного походження від тривалості зберігання та покоління.

2. Встановити, чи існує генотипова обумовленість досліджуваних показників.

Матеріали і методи досліджень. Дослідження проводили на базі Дослідної станції луб'яних культур Інституту сільського господарства Північного Сходу НААН України у 2007-2012 роках. Самозапилення рослин сортів однодомних конопель середньоросійського еколого-географічного типу Глухівські 58 (Вікторія), Гляна, Глесія та південного (Золотоніські 15) проводили в умовах вегетаційного будинку 3 використанням індивідуальних ізоляторів із агроволокна. Очищене насіння зберігали у паперових пакетах в умовах лабораторії. Якісні показники насіння урожаю 2008-2012 pp. визначали у 2012 р. через місяць після збирання (насіння конопель проростає без періоду спокою).

Матеріал пророщували за температури $20{ }^{\circ} \mathrm{C}$ на фільтрувальному папері, енергію проростання визначали на третю добу, схожість - на сьому, згідно з прийнятими рекомендаціями [4]. Повторність для суміші насіння кожної лінії й року двократна, по 100 шт. насінин. Показники окремих самозапилених ліній визначали в однократній повторності для трьох різних зразків. Статистичну обробку даних здійснювали за методикою польового досліду [3].

Результати досліджень. Дослідження показують, що зі збільшенням тривалості зберігання насіння енергія проростання й схожість знижуються (табл. 1).

\section{1. Залежність енертї̈ проростання і схожості насіння (\%) самозапилених ліній конопель} від покоління та тривалості зберігання (2008-2012 рр.)

\begin{tabular}{|c|c|c|c|c|c|}
\hline \multirow{2}{*}{ Сорт, лінія } & \multicolumn{5}{|c|}{ Рік урожаю } \\
\hline & 2008 & 2009 & 2010 & 2011 & 2012 \\
\hline Глухівські 58 & $1 / 4$ & $36 / 42$ & $78 / 81$ & $80 / 82$ & $81 / 92$ \\
\hline $\mathrm{I}_{1}$ Глухівські 58 & $0 / 3$ & $26 / 28$ & $77 / 80$ & $64 / 81$ & $76 / 90$ \\
\hline $\mathrm{I}_{2}$ Глухівські 58 & - & $22 / 33$ & $60 / 80$ & $62 / 80$ & $75 / 84$ \\
\hline $\mathrm{I}_{3}$ Глухівські 58 & - & - & $50 / 70$ & $52 / 81$ & $70 / 85$ \\
\hline $\mathrm{I}_{4}$ Глухівські 58 & - & - & - & $51 / 70$ & $65 / 70$ \\
\hline $\mathrm{I}_{5}$ Глухівські 58 & - & - & - & - & $57 / 77$ \\
\hline Гляна & - & - & - & - & $94 / 99$ \\
\hline $\mathrm{I}_{1}$ Гляна & - & - & - & - & $93 / 99$ \\
\hline Глесія & - & - & $55 / 67$ & $88 / 95$ & $91 / 100$ \\
\hline $\mathrm{I}_{1}$ Глесія & - & - & $50 / 60$ & $86 / 92$ & $97 / 97$ \\
\hline $\mathrm{I}_{2}$ Глесія & - & - & - & $80 / 95$ & $87 / 95$ \\
\hline $\mathrm{I}_{3}$ Глесія & - & - & - & - & $70 / 70$ \\
\hline Золотоніські 15 & $1 / 2$ & $51 / 60$ & $58 / 78$ & $85 / 92$ & $86 / 93$ \\
\hline $\mathrm{I}_{1}$ Золотоніські 15 & $0 / 1$ & $46 / 56$ & $50 / 72$ & $81 / 82$ & $84 / 85$ \\
\hline $\mathrm{I}_{2}$ Золотоніські 15 & - & $20 / 21$ & $50 / 70$ & $51 / 75$ & $80 / 80$ \\
\hline $\mathrm{I}_{3}$ Золотоніські 15 & - & - & $49 / 68$ & $49 / 80$ & $79 / 79$ \\
\hline $\mathrm{I}_{4}$ Золотоніські 15 & - & - & - & $46 / 79$ & $79 / 85$ \\
\hline $\mathrm{I}_{5}$ Золотоніські 15 & - & - & - & - & $78 / 80$ \\
\hline
\end{tabular}

Примітка. Чисельник - енергія проростання, знаменник - схожість насіння. 
Ця особливість характерна для всіх без винятку досліджуваних сортів і самозапилених ліній. Наприклад, енергія проростання насіння сорту Глухівські 58 урожаю 2008 р. становить 1, 2009 p. - 36, 2010 p. $-78,2011$ p. -80 i 2012 p. $81 \%$; схожість - 4, 42, 81, 82 і $92 \%$ відповідно. Енергія проростання насіння сорту Золотоніські 15 урожаю 2008 р. становить 1, 2009 р. - 51, 2010 p. $-58,2011$ p. -85 i 2012 p. $-86 \%$. Cxожість - 2, 60, 78, 92 і 93 \% відповідно. У І ${ }_{1}$ Глухівські 58 енергія проростання й схожість становлять по роках 0 i 3, 26 i 28, 77 i 80, 64 i 81, 76 i 90 \%, y $\mathrm{I}_{1}$ Золотоніські 15 - 0 і 1, 46 і 56, 50 і 72, 81 і 82, 84 і $85 \%$ відповідно. Досить різко знижується схожість через 3 і фактично втрачається через 4 роки за звичайних умов зберігання.

У разі самозапилення спостерігається зниження показників енергії проростання, що характерно для всіх досліджуваних зразків (табл. 1). Так, дана ознака послідовно знижується у популяції сорту Глухівські 58 із 36 до $22 \%$ у I I $_{2}(2009$ р.), iз 78 до $50 \%$ - у I $\mathrm{I}_{3}\left(2010\right.$ р.), із 80 до $51 \%-$ y I$_{4}$ (2011 p.) і 381 до $57 \%$ - у I 5 (2012 р.); у популяції сорту Глесія - 355 до 50 \% у I I $_{2}(2010$ р.), із 88 до $80 \%$ - у $\mathrm{I}_{2}\left(2011\right.$ р.) і з 91 до $70 \%-$ у $\mathrm{I}_{3}$ (2012 р.); у популяції сорту Золотоніські 15 - із 51 до $20 \%$ у $\mathrm{I}_{2}(2009$ р.), із 58 до $49 \%-$ у I (2010 p.), із 85 до $46 \%$ - у I 4 (2011 p.) і з 86 до $78 \%$ - у I $\mathrm{I}_{5}$ (2012 р.). У даному випадку проявляється інцухт-депресія, що полягає у зниженні сили розвитку зародка насінини, здатності до проростання, що $є$ наслідком пригніченого формування насіння після запилення і запліднення, в т. ч. й розвитку ендосперму.

Стосовно схожості насіння, то в окремих випадках існує лише тенденція до зниження даного показника. Чітка закономірність спостерігається не завжди. Однак можна припустити, що через зміну енергії проростання у самозапилених ліній польова схожість і характер сходів будуть відмінні від сортових у гірший бік, що треба враховувати у селекційній роботі.

Зважаючи на наявність чіткого зв'язку між поколінням ліній і енергією проростання, враховуючи те, що результати вимірювань здійснені в інтервальних шкалах і розподіл величин можна вважати нормальними, - побудуємо рівняння лінійної регресії (див. рис.). Це дає змогу прогнозувати прояв даної ознаки у певного покоління самозапиленої лінії.

Проаналізувавши межі варіювання ознак енергії проростання і схожості насіння різних сімей самозапилених ліній (табл. 2), слід констатувати значний розмах варіації (h) даних ознак, зокрема першої від 1 до 68 і другої - від 2 до 68, що свідчить про генотипову залежність ознак енергії проростання й схожості тієї чи іншої лінії (зразка).
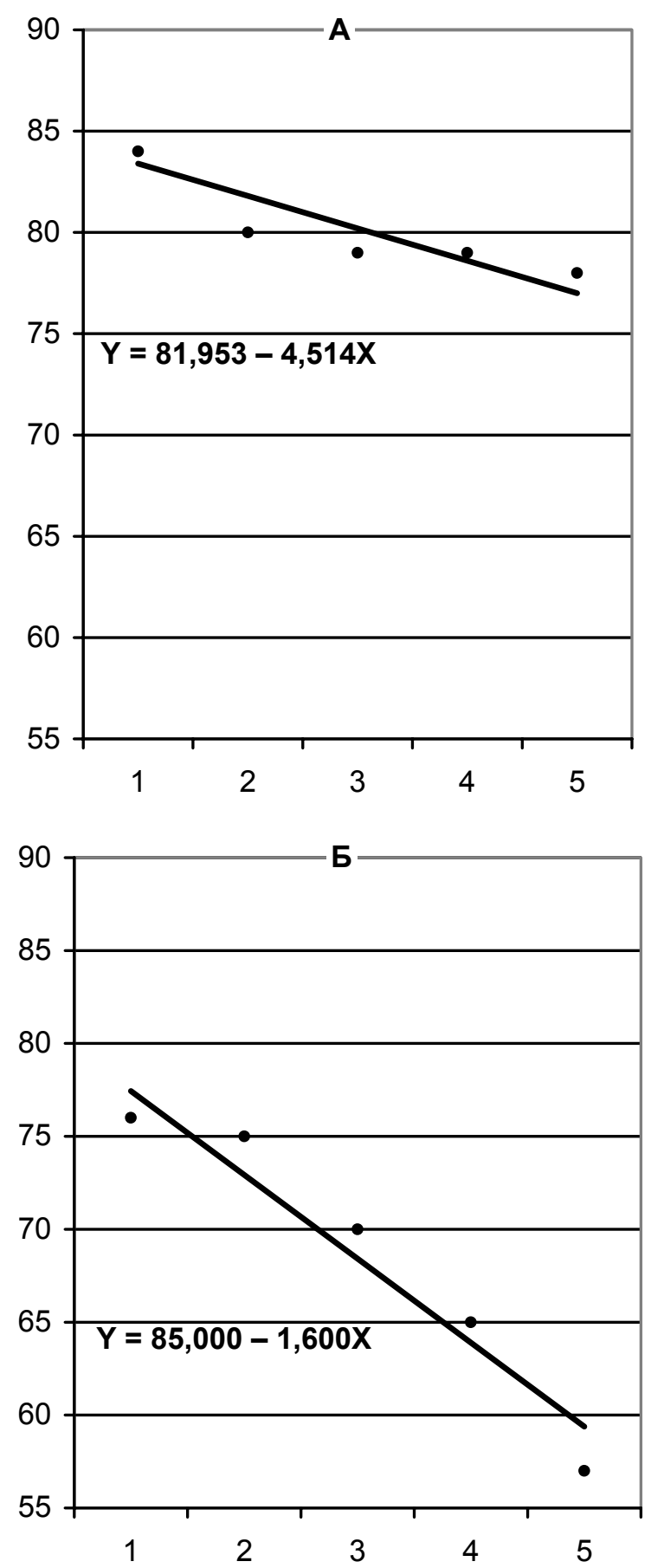

Рис. Залежність енертії проростання насіння конопель від покоління самозапиленої лінї̈ (A - для ліній сорту Глухівські 58, рівняння лінійної регресії $Y=81,953$ - 4,514X; Б - для ліній сорту Золотоніські 15, рівняння лінійної регресії $Y=85,000-1,600 X)$ 
2. Межі варіювання ознак енертї̈ проростання і схожості насіння (\%) різних сімей самозапилених ліній конопель

\begin{tabular}{|c|c|c|c|c|c|}
\hline \multirow{2}{*}{ Рік } & \multirow{2}{*}{ Лінія } & \multicolumn{2}{|c|}{ Енергія проростання } & \multicolumn{2}{|c|}{ Схожість } \\
\hline & & $\min -\max$ & $\mathrm{h}$ & $\min -\max$ & $\mathrm{h}$ \\
\hline \multirow{2}{*}{2008} & $\mathrm{I}_{1}$ Глухівські 58 & $0-1$ & 1 & $2-9$ & 7 \\
\hline & $\mathrm{I}_{1}$ Золотоніські 15 & $0-1$ & 1 & $0-2$ & 2 \\
\hline \multirow{4}{*}{2009} & $\mathrm{I}_{1}$ Глухівські 58 & $9-77$ & 68 & $10-78$ & 68 \\
\hline & $\mathrm{I}_{2}$ Глухівські 58 & $1-57$ & 56 & $3-63$ & 60 \\
\hline & $\mathrm{I}_{1}$ Золотоніські 15 & $1-39$ & 38 & $1-40$ & 39 \\
\hline & $\mathrm{I}_{2}$ Золотоніські 15 & $1-52$ & 51 & $1-54$ & 53 \\
\hline \multirow{13}{*}{2012} & $\mathrm{I}_{1}$ Глухівські 58 & $52-84$ & 32 & $83-100$ & 17 \\
\hline & $\mathrm{I}_{2}$ Глухівські 58 & $50-76$ & 26 & $59-93$ & 34 \\
\hline & $\mathrm{I}_{3}$ Глухівські 58 & $60-90$ & 30 & $60-90$ & 30 \\
\hline & $\mathrm{I}_{4}$ Глухівські 58 & $60-70$ & 10 & $70-75$ & 5 \\
\hline & $\mathrm{I}_{5}$ Глухівські 58 & $30-70$ & 40 & $60-90$ & 30 \\
\hline & $\mathrm{I}_{1}$ Глесія & $90-100$ & 10 & $98-100$ & 2 \\
\hline & $\mathrm{I}_{2}$ Глесія & 59-97 & 38 & $50-100$ & 50 \\
\hline & $\mathrm{I}_{3}$ Глесія & $50-90$ & 40 & $50-100$ & 50 \\
\hline & $\mathrm{I}_{1}$ Золотоніські 15 & $75-90$ & 15 & $90-97$ & 7 \\
\hline & $\mathrm{I}_{2}$ Золотоніські 15 & $75-86$ & 11 & $78-88$ & 10 \\
\hline & $\mathrm{I}_{3}$ Золотоніські 15 & $61-90$ & 29 & $64-100$ & 36 \\
\hline & $\mathrm{I}_{4}$ Золотоніські 15 & $75-90$ & 15 & $80-90$ & 10 \\
\hline & $\mathrm{I}_{5}$ Золотоніські 15 & $77-80$ & 3 & $79-81$ & 2 \\
\hline
\end{tabular}

\section{Висновки:}

1. Зі збільшенням тривалості зберігання насіння конопель енергія його проростання й схожість знижуються.

2. У разі самозапилення спостерігається чітке зниження показників енергії проростання від

\section{БІБЛІОГРАФІЯ}

1. Біологічне рослинництво : [навч. посібн.] / Зінченко О. І., Алексєєва О. С., Приходько П. М. [та ін.] ; за ред. О. І. Зінченка. - К. : Вища школа, 1996. - $239 \mathrm{c}$.

2. Гуляев Г. В. Генетика : [учебн. для студ. агроном. спец. с.-х. вузов] / Г. В. Гуляев. - [2-е изд., перераб. и доп.]. - М. : Колос, 1977. - 360 с. (Учебники и учебн. пособия для высш. с.-х. учеб. заведений).

3. Доспехов Б. А. Методика полевого опыта : [учебн. для студ. агроном. спец. с.-х. вузов] / Б. А. Доспехов. - [3-е изд., перераб. и доп.]. - М. : Колос, $1973 .-336 \mathrm{c}$.

4. Лихочвор В. В. Рослинництво. Технології вирощування сільськогосподарських культур : [навч. популяції сорту до $\mathrm{I}_{5}$, що характерно для всіх досліджуваних ліній (зразків).

3. Значні межі варіювання ознак енергії проростання і схожості (розмах варіації від 1 до 68) дають підстави стверджувати про генотипову залежність даної ознаки.

посібн.] / В. В. Лихочвор. - [2-ге вид., випр.]. К. : Центр навчальної літератури, 2004. - 808 с.

5. Міщенко C. B. Актуальні напрями дослідження впливу інбридингу на зміну біологічних і селекційних ознак однодомних конопель / С. В. Міщенко, І. М. Лайко, В. Г. Вировець // Актуальні питання розвитку технічних та лікарських культур : наук.-практ. конф. молодих вчених, 6-8 грудня 2011 р. - Суми, 2012. - С. 6-12.

6. Степанов $Г$. С. Метод інцухту в селекції конопель / Г. С. Степанов // Вісник сільськогосподарської науки. - 1975. - № 5. - С. 58-61.

7. Шевиов И. А. Использование инбридинга у растений / И. А. Шевцов. - К. : Наукова думка, 1983. -272 c. 